\title{
SISTEM PAKAR DIAGNOSA HAMA DAN PENYAKIT TANAMAN CABAI BESAR MENGGUNAKAN METODE CERTAINTY FACTOR
}

\author{
Tomi Winanto ${ }^{1)}$, Yustina Retno Wahyu Utami ${ }^{2)}$, Sri Hariyati Fitriasih ${ }^{3)}$ \\ ${ }^{1,2)}$ Program Studi Teknik Informatika, STMIK Sinar Nusantara Surakarta \\ ${ }^{3)}$ Program Studi Manajemen Informatika, STMIK Sinar Nusantara Surakarta \\ 1) tomystarks@gmail.com, ${ }^{2)}$ yustina_retno@sinus.ac.id, ${ }^{3)}$ fitriasih@ gmail.com
}

\begin{abstract}
Chili plants have a lot of pest and disease attacks. Pest and disease attacks potentially reduce the production of chilli and even cause crop failure. In addition, the limited number of extension workers and the lack of knowledge of practitioners / chili farmers inhibits efforts to control pests and diseases of chili plants. Therefore, the authors propose an expert system to diagnose pests and diseases in large chili plants using the Certainty Factor method. The Certainty Factor method is used to perform calculations by providing an expert's level of confidence. Expert systems relate symptoms and diseases as well as pest and disease control solutions of large chili plants. The data were obtained based on interviews with experts at the Organization for Industrial, Spiritual and Cultural Advancement (OISCA) Training Center Karanganyar. The data obtained was analyzed and expert system design application was made using UML diagram. The design is continued with the implementation of expert system application into PHP programming and MySQL database. The test results show that the system can diagnose pests and diseases of large chili plants like an expert.
\end{abstract}

Keyword: certainty factor, expert system, pest and disease, large chili plant (Capsicum Annuum Longum).

\section{PENDAHULUAN}

Komputer saat ini merupakan perangkat yang sudah menjangkau hampir sebagian besar masyarakat. Kemajuan teknologi dalam bidang komputer telah menjadikan komputer sebagai alat bantu untuk memudahkan pekerjaan manusia dalam berbagai aspek. Salah satu contohnya menghasilkan suatu cara pendekatan yang sering disebut dengan kecerdasan buatan. Salah satu pengembangan kecerdasan buatan yaitu sistem pakar yang dalam hal ini sistem pakar diagnosa hama dan penyakit tanaman.

Cabai memiliki sejarah serangan hama dan penyakit yang cukup banyak. Sebut saja hama thrips, lalat buah, kutu daun, dan tungau yang banyak meresahkan petani. Tidak hanya itu, penyakit seperti layu bakteri, layu fusarium, antraknosa, dan penyakit virus kuning bahkan lazim ditemui di beberapa sentra produksi cabai. Serangan hama dan penyakit ini berpotensi menurunkan produksi cabai. Bahkan pada beberapa kasus, serangan hama dan penyakit mampu menyebabkan gagal panen.

Terkadang petani mengetahui ketika tanamannya diserang hama atau penyakit, tetapi petani tidak tahu hama atau penyakit apa yang sedang menyerang tanamannya. Masalah ini berkaitan erat dalam upaya pengendalian hama dan penyakit tanaman cabai besar secara strategis. Seorang pakar dibutuhkan untuk bertindak sebagai media bantu, mengingat terbatasnya pengetahuan para praktisi petani cabai dan kurangnya tenaga penyuluh.

Media yang dapat membantu permasalahan diatas adalah dengan dibuatnya Sistem Pakar Diagnosa Hama dan Penyakit Tanaman Cabai Besar. Pada penelitian ini metode Certainty Factor diterapkan untuk mengakomodasi tingkat keyakinan pakar sehingga 
dapat diterapkan untuk membuat Sistem Pakar Diagnosa Hama dan Penyakit Tanaman Cabai Besar Menggunakan Metode Certainty Factor dan didapatkan prosentase nilai keyakinan serangan hama atau penyakit beserta solusi pengendaliannya.

\section{TINJAUAN PUSTAKA}

\subsection{Penelitian Sebelumnya}

Penelitian tentang sistem pakar telah banyak dilakukan. Penelitian di bidang kesehatan sistem pakar diimplementasikan untuk deteksi kanker serviks (Rochana, Kusumaningrum, \& Utami, 2017). Gejala yang digunakan meliputi pendarahan, keputihan, nyeri panggul, penurunan berat badan, dan nyeri kandung kemih. Akurasi sitem yang diusulkan mencapai 80\%. Selain itu, sistem pakar juga diterapkan untuk mengetahui hama wereng untuk tanaman padi (Setianto, Widada, \& Utami, 2017). Sistem yang diusulkan untuk mendeteksi serangan hama wereng menggunakan fuzzy Tsukamoto. Akurasi sistem yang diperoleh sebesar $80 \%$. Metode Forward Chaining diterapkan untuk deteksi penyakit namun dianggap belum bisa memecahkan ketidakpastian diagnosa penyakit (Ulya, Putri, \& Furqon, 2014). Data penyakit menunjukkan terdapat 9 jenis penyakit kulit pada anak beserta 30 gejala berkaitan. Penelitian mengenai sistem pakar dengan metode certainty factor juga dilakukan untuk diagnosa dini penyakit telinga hidung dan tenggorokan berdasarkan gejala suara serak, nyeri saat bicara atau menelan, batuk, dan leher bengkak. (Khasanah, Utami, \& Nugroho, 2012).

Penelitian ini mengusulkan suatu sistem untuk diagnosa hama dan penyakit pada tanaman cabai besar menggunakan metode certainty factor.

\subsection{Sistem Pakar}

Sistem pakar merupakan sistem yang berbasis pengetahuan yang menyediakan solusi dengan mengadopsi kemampuan pakar untuk menyelesaikan masalah dalam suatu domain pengetahuan yang spesifik. Umumnya pengetahuan pada sistem pakar diambil dari seorang atau tim yang merupakan pakar pada bidang tertentu. Dengan sistem pakar ini, orang awam pun dapat dibantu dalam menyelesaikan masalahnya atau hanya sekedar mencari informasi berkualitas yang sebenarnya hanya dapat diperoleh dari para pakar di bidangnya (Sihombing \& Ayub, 2010).

\subsection{Certainty Factor}

Certainty Factor merupakan suatu metode untuk membuktikan ketidakpastian pemikiran seorang pakar, dimana untuk mengakomodasi hal tersebut seseorang biasanya menggunakan certainty factor untuk menggambarkan tingkat keyakinan pakar terhadap masalah yang sedang dihadapi (Sutojo, 2010).

Nilai kepercayaan didapatkan dari interpretasi seorang pakar yang kemudian dirubah/dikonversi menjadi nilai kepercayaan dengan ketentuan seperti pada Tabel 1.

Tabel 1. Nilai evidence tingkat keyakinan pakar

\begin{tabular}{|l|c|}
\hline \multicolumn{1}{|c|}{ Uncertainty Term } & CF \\
\hline Pasti tidak & -1 \\
\hline Hampir pasti tidak & $-0,8$ \\
\hline Kemungkinan besar tidak & $-0,6$ \\
\hline Mungkin tidak & $-0,4$ \\
\hline Tidak tahu & $-0,2$ sampai 0,2 \\
\hline Mungkin & 0,4 \\
\hline Kemungkinan besar & 0,6 \\
\hline Hampir pasti & 0,8 \\
\hline Pasti & 1 \\
\hline
\end{tabular}


Perhitungan $\mathrm{CF}$ dikerjakan dengan ketentuan berikut :

$$
\begin{aligned}
& M B=M B \text { Lama }+(M B \text { Baru } *(1-M B \text { Lama })) \\
& M D=M D \text { Lama }+(M D \text { Baru } *(1-M D \text { Lama })) \\
& C F(H, E)=M B(H, E)-M D(H, E)
\end{aligned}
$$

Keterangan :

$\mathrm{CF}(\mathrm{H}, \mathrm{E})$ : Certainty Factor (Faktor Kepastian) dari hipotesis $\mathrm{H}$ yang dipengaruhi oleh gejala (evidence) E. Besarnya CF berkisar antara -1 sampai 1. Nilai -1 menunjukkan ketidakpercayaan mutlak sedangkan nilai 1 menunjukkan kepercayaan mutlak.

MB(H,E) : Ukuran kenaikan kepercayaan (Measure of Belief) terhadap hipotesis H yang dipengaruhi oleh gejala E.

$\mathrm{MD}(\mathrm{H}, \mathrm{E})$ : Ukuran kenaikan ketidakpercayaan (Measure of Disbelief) terhadap hipotesis $\mathrm{H}$ yang dipengaruhi oleh gejala E.

\subsection{Cabai Besar}

Cabai merupakan salah satu komoditas hortikultura yang memiliki sejarah serangan hama dan penyakit yang cukup banyak. Sebut saja hama thrips, lalat buah, kutu daun, dan tungau yang banyak meresahkan petani. Tidak hanya itu, penyakit seperti layu bakteri, layu fusarium, antraknosa, dan penyakit virus kuning bahkan lazim ditemui di beberapa sentra produksi cabai. Serangan hama dan penyakit ini berpotensi menurunkan produksi cabai. Bahkan pada beberapa kasus, serangan hama dan penyakit mampu menyebabkan gagal panen (Hamid \& Haryanto, 2012).

Terjadinya kegagalan /panen, terutama pada tanaman sayuran/palawija khususnya tanaman cabe merah dapat disebabkan bencana alam yang melanda suatu daerah tertentu dan juga terserang oleh hama dan penyakit. Sebagian besar kegagalan panen disebabkan karena tanaman diserang oleh hama dan penyakit. Kadang-kadang petani tahu kalau tanamannya diserang hama/penyakit, tetapi petani tidak tahu hama/penyakit apa yang sedang menyerang tanamannya (Kaswidjanti, 2011).

\subsection{PHP}

Bahasa pemrograman PHP adalah salah satu bahasa pemrograman untuk aplikasi web yang terkenal. Bahasa ini dieksekusi oleh server web setiap kali ada permintaan. Banyak sekali keuntungan menggunakan PHP, antara lain, penggunaan sintak pemrograman bahasa $\mathrm{C}$ yang sudah terkenal, tidak adanya tipe-tipe data untuk variabel yang digunakan, banyaknya fungsi yang disediakan untuk ekspansi dengan menggunakan sistem lain. Selain itu juga PHP merupakan bahasa pemrograman yang sifatnya open source. Artinya bahasa ini boleh dipakai oleh siapapun juga, dan untuk apapun tanpa harus mengeluarkan biaya untuk lisensinya. Sifat open source juga, menjadikan bahasa ini boleh dimodifikasi untuk memenuhi kebutuhan pengguna. Karena sifatnya yang dieksekusi oleh web server, maka tidak dibutuhkan compiler khusus untuk editor PHP (Kandaga \& Sarean, 2010).

\subsection{MYSQL}

MySQL adalah sebuah perangkat lunak sistem manajemen basis data SQL DBMS (Database Management System) dan sekian banyak DBMS, seperti Oracle, MS SQL, Postgre SQL, dan lain-lain. MySQL merupakan DBMS yang multithread, multi-user yang bersifat gratis di bawah lisensi GNU GPL (General Public Licence). MySQL bersifat gratis atau open source sehingga kita bisa menggunakannya secara gratis. Pemrograman PHP juga sangat mendukung/support dengan database MySQL (Anhar, 2010). 


\section{METODE PENELITIAN}

\subsection{Sumber Data}

Data yang digunakan dalam penelitian ini diambil dari pakar yaitu tenaga instruktur pertanian pada OISCA Training Centre Karanganyar yang beralamatkan di Jl. TP. Joko Songo Km.1,2 Doplang, Karangpandan, Karanganyar.

\subsection{Metode Pengumpulan Data}

Metode pengumpulan data untuk sistem pakar ini meliputi:

- Wawancara

Tahap wawancara ini dilakukan dengan konsultasi dan tanya jawab langsung kepada instruktur pertanian yang bekerja pada OISCA Training Centre Karanganyar dengan mengajukan pertanyaan yang berkaitan dengan penelitian yaitu hama dan penyakit tanaman cabai besar serta gejala dan solusi pengendaliannya.

- Observasi

Observasi dilakukan dengan kunjungan dan pengamatan langsung pada lahan praktek tanaman cabai besar milik OISCA Training Centre Karanganyar didampingi oleh tenaga instruktur pertanian.

- Studi Pustaka

Studi kepustakaan untuk mendapatkan teori pendukung seperti pengetahuan sistem pakar, Certainty Factor melalui literatu-literatur seperti buku dan jurnal ilmiah. Buku yang dimaksud salah satunya berjudul Teknologi Budidaya Hortikultura oleh OISCA Training Centre Karanganyar.

\subsection{Metode Pengembangan Sistem}

Metode pengembangan sistem yang diusulkan meliputi:

- Analisis Sistem

Analisis sistem dilakukan berdasarkan data hama penyakit serta gejala dan informasi yang diperlukan untuk implementasi metode Certainty Factor untuk diagnosa hama dan penyakit tanaman cabai besar dengan proses konsultasi untuk didapatkan hasil diagnosa berupa laporan jenis hama dan penyakit tanaman cabai besar beserta pengendaliannya.

\section{- Perancangan Sistem}

Perancangan sistem yang dilakukan meliputi perancangan proses dengan permodelan UML, serta perancangan input dan perancangan output berupa rancangan antarmuka program aplikasi sistem pakar yang akan dibuat.

- Implementasi Sistem

Tahap implementasi dilakukan dengan cara melakukan pengkodean program dengan menggunakan bahasa PHP dan basis data MySQL serta memanfaatkan metode Certainty Factor dalam membangun sistem pakar diagnosa hama dan penyakit tanaman cabai besar.

- Pengujian Sistem

Pengujian sistem dilakukan dengan menguji aplikasi dengan pengujian fungsional sistem. Pengujian fungsional dilakukan dengan metode black box untuk mengetahui fungsionalitas dari sistem yang sudah dibuat apakah sudah berfungsi dengan benar sesuai dengan yang diharapkan. Selain itu, juga akan dibandingkan hasil diagnosa sistem pakar dengan hasil diagnosa seorang pakar terhadap gejala yang dipilih.

\section{HASIL DAN PEMBAHASAN}

4.1. Perhitungan Diagnosa Hama dan Penyakit Tanaman Cabai Besar Menggunakan Metode Certainty Factor 
Tahap awal dimulai dengan pengumpulan data hama dan penyakit beserta semua gejala dengan nilai kepercayaan yang didapat dari wawancara dengan seorang pakar.

Pengguna akan memilih gejala yang dialami sesuai dengan daftar gejala. Contoh gejala yang dipilih pengguna seperti pada Tabel 2 .

Tabel 2. Contoh gejala yang dipilih saat diagnosa

\begin{tabular}{|c|l|}
\hline No & \multicolumn{1}{|c|}{ Nama Gejala } \\
\hline 1 & Tanaman layu mendadak \\
\hline 2 & Tanaman layu hanya saat panas terik \\
\hline 3 & Akar tanaman layu berjamur \\
\hline
\end{tabular}

Tahap berikutnya menentukan semua jenis hama dan penyakit yang memiliki ciri gejala sesuai dengan gejala terpilih. Semua nama gangguan sesuai dengan gejala terpilih di atas diperlihatkan pada Tabel 3.

Tabel 3. Semua jenis gangguan sesuai dengan gejala terpilih

\begin{tabular}{|c|l|l|}
\hline No & \multicolumn{1}{|c|}{$\begin{array}{c}\text { Nama } \\
\text { Gangguan }\end{array}$} & \multicolumn{1}{c|}{ Nama Gejala } \\
\hline \multirow{2}{*}{1} & Layu & Cendawan \\
& Fusarium & Tanaman layu mendadak \\
\cline { 3 - 3 } & Tanaman layu hanya saat panas terik \\
\cline { 3 - 3 } 2 & Layu Bakteri & Akar tanaman layu berjamur \\
\hline
\end{tabular}

Masing-masing gangguan dan gejala akan dihubungkan dengan nilai kepercayaan yang diperoleh dari seorang pakar pada saat pengumpulan data.

Tabel 4. Contoh nilai kepercayaan dari pakar

\begin{tabular}{|c|l|l|c|c|}
\hline No & \multicolumn{1}{|c|}{$\begin{array}{c}\text { Nama } \\
\text { Gangguan }\end{array}$} & Nama Gejala & MB & MD \\
\hline \multirow{2}{*}{1} & $\begin{array}{l}\text { Layu } \\
\text { Cendawan }\end{array}$ & Tanaman layu mendadak & 0,8 & 0,1 \\
\cline { 2 - 5 } & Fusarium & Tanaman layu hanya saat panas terik & 0,8 & 0 \\
\cline { 2 - 5 } & Akar tanaman layu berjamur & 0,8 & 0,1 \\
\hline 2 & Layu Bakteri & Tanaman layu mendadak & 0,8 & 0,2 \\
\hline
\end{tabular}

Perhitungan nilai $\mathrm{MB}$ penyakit layu cendawan fusarium untuk gejala pertama dan kedua :

$$
\begin{aligned}
& M B=M B \text { Lama }+(M B \text { Baru } *(1-\text { MB Lama })) \\
& M B=0,8+(0,8 *(1-0,8)) \\
& M B=0,8+(0,8 * 0,2) \\
& M B=0,8+0,16 \\
& M B=0,96
\end{aligned}
$$

Perhitungan pertama didapat nilai dari MB Sementara yang akan dijadikan sebagai MB Lama pada perhitungan berikutnya dengan gejala ketiga :

$M B=M B$ Lama $+(M B$ Baru $*(1-M B$ Lama $))$

$M B=0,96+(0,8 *(1-0,96))$

$M B=0,96+(0,8 * 0,04)$

$M B=0,96+0,032$

$M B=0,992$ kedua :

Perhitungan nilai MD penyakit layu cendawan fusarium untuk gejala pertama dan

$M D=M D$ Lama $+($ MD Baru $*(1-$ MD Lama $))$

$M D=0,1+(0 *(1-0,1))$

$M D=0,1+0$

$M D=0,1$ 
Perhitungan pertama didapat nilai dari MD Sementara yang akan dijadikan sebagai MD Lama pada perhitungan berikutnya dengan gejala ketiga :

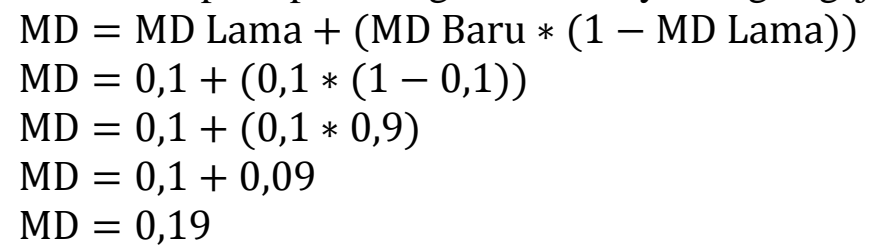

Setelah didapat nilai MB dan MD maka dapat dicari nilai $\mathrm{CF}$ penyakit layu cendawan fusarium :

$$
\begin{aligned}
& C F=M B-M D \\
& C F=0,992-0,19 \\
& C F=0,802
\end{aligned}
$$
$80,2 \%$.

Hasil perhitungan akhir untuk penyakit layu cendawan fusarium adalah 0,802 atau

Penyakit kedua yaitu layu bakteri hanya memiliki 1 gejala terpilih dengan nilai $\mathrm{MB}=$ 0,8 dan $\mathrm{MD}=0,2$ maka dapat dicari nilai $\mathrm{CF}$ penyakit layu bakteri

$$
\begin{aligned}
& \mathrm{CF}=\mathrm{MB}-\mathrm{MD} \\
& \mathrm{CF}=0,8-0,2 \\
& \mathrm{CF}=0,6
\end{aligned}
$$

Hasil perhitungan akhir untuk penyakit layu bakteri adalah 0,6 atau $60 \%$.

Langkah-langkah di atas dilakukan untuk semua penyakit yang berkaitan dengan gejalan tersebut. Hasil dari semua perhitungan, diperoleh persentase penyakit yang disajikan pada Tabel 5.

Tabel 5. Hasil akhir perhitungan

\begin{tabular}{|c|l|c|}
\hline No & \multicolumn{1}{|c|}{ Nama Gangguan } & $\begin{array}{c}\text { Kemungkinan } \\
\text { Terserang }\end{array}$ \\
\hline 1 & Layu Cendawan Fusarium & $80,2 \%$ \\
\hline 2 & Layu Bakteri & $60 \%$ \\
\hline
\end{tabular}

Dari gejala tanaman layu mendadak, tanaman layu hanya saat panas terik, dan akar tanaman layu berjamur, maka kemungkinan penyakit layu cendawan fusarium $80 \%$ dan Layu Bakteri 60\%.

\subsection{Analisa Sistem}

Sistem pakar diagnosa hama dan penyakit tanaman cabai besar ini dikembangkan dan didesain untuk diterapkan pada Kantor OISCA Training Centre Karanganyar. Pembuatan sistem pakar ini bertujuan untuk memudahkan praktisi/petani cabai dalam melakukan diagnosa hama dan penyakit tanaman cabai besar. Diagnosa dilakukan dengan memilih gejala yang dialami untuk kemudian dikalkulasi untuk didapatkan hasil diagnosa berupa jenis penyakit dan solusi pengendalian urut berdasarkan persentase kemungkinan tanaman terserang hama atau penyakit.

\subsection{Desain Sistem}

\section{a. Use Case Diagram}

Sistem pakar yang dibangun memiliki dua aktor yakni admin dan user. Admin dapat melakukan pengelolaan data hama dan penyakit serta data gejala, sedangkan user dapat melakukan konsultasi terhadap gejala yang dialami pada tanaman cabai. Keseluruhan interaksi aktor dan kegiatan dalam sistem digambarkan dalam use case diagram seperti pada Gambar 1. 


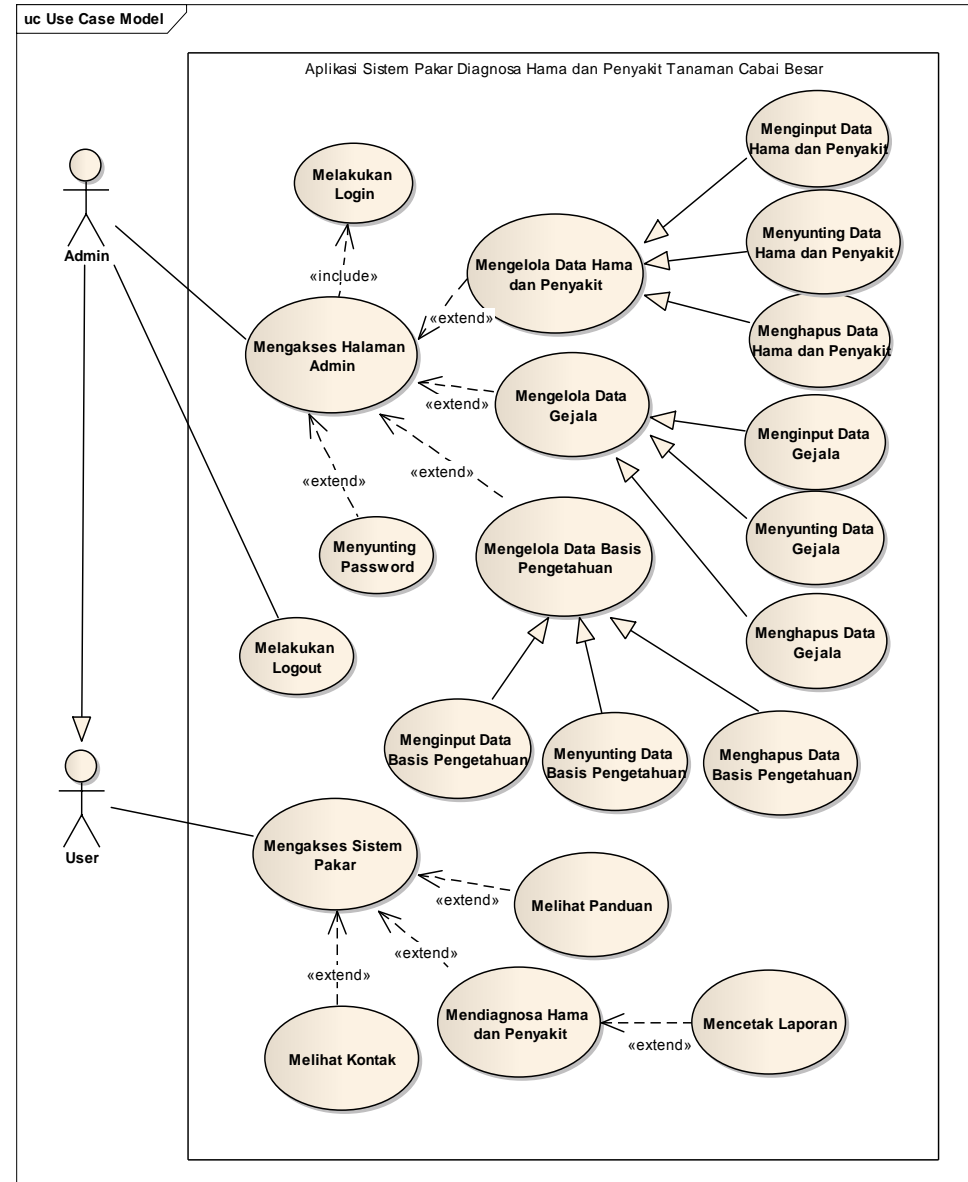

Gambar 1. Use Case Diagram Sistem Pakar Diagnosa Hama dan Penyakit Tanaman Cabai Besar

Tabel 6. Aktor dalam Use Case Diagram beserta peran fungsinya

\begin{tabular}{|l|l|}
\hline \multicolumn{1}{|c|}{ Nama Aktor } & \multicolumn{1}{|c|}{ Peran/ Fungsi } \\
\hline Admin & $\begin{array}{l}\text { Admin memiliki hak akses penuh terhadap aplikasi sistem pakar } \\
\text { dengan akses halaman login admin untuk mengelola data } \\
\text { diantaranya menambah, menyunting, dan menghapus data hama } \\
\text { dan penyakit, gejala dan data basis pengetahuan yang tersimpan } \\
\text { di dalam database. }\end{array}$ \\
\hline User & $\begin{array}{l}\text { User merupakan sebutan bagi pengguna / operator aplikasi } \\
\text { sistem pakar yang hanya dapat mengoperasikan aplikasi } \\
\text { diagnosa sistem pakar dan mencetak hasil diagnosa. }\end{array}$ \\
\hline
\end{tabular}

\subsection{Implementasi Sistem}

Pada tahap implementasi dengan melakukan pengkodean program dari sistem yang akan dibuat menggunakan bahasa pemrograman PHP dan basis data MySQL, berikut ini merupakan hasil tampilan program dari sistem pakar diagnosa hama dan penyakit tanaman cabai besar menggunakan metode certainty factor yang telah dibuat:

\section{a. Tampilan halaman utama}

Halaman utama merupakan halaman awal atau halaman standar ketika aplikasi sistem pakar dimuat untuk pertama kali. Halaman utama berisi pengenalan atau selayang pandang mengenai tanaman cabai, hama dan penyakit, gejala penyakit dan lain sebagainya. Halaman utama aplikasi ditunjukkan pada Gambar 2. 


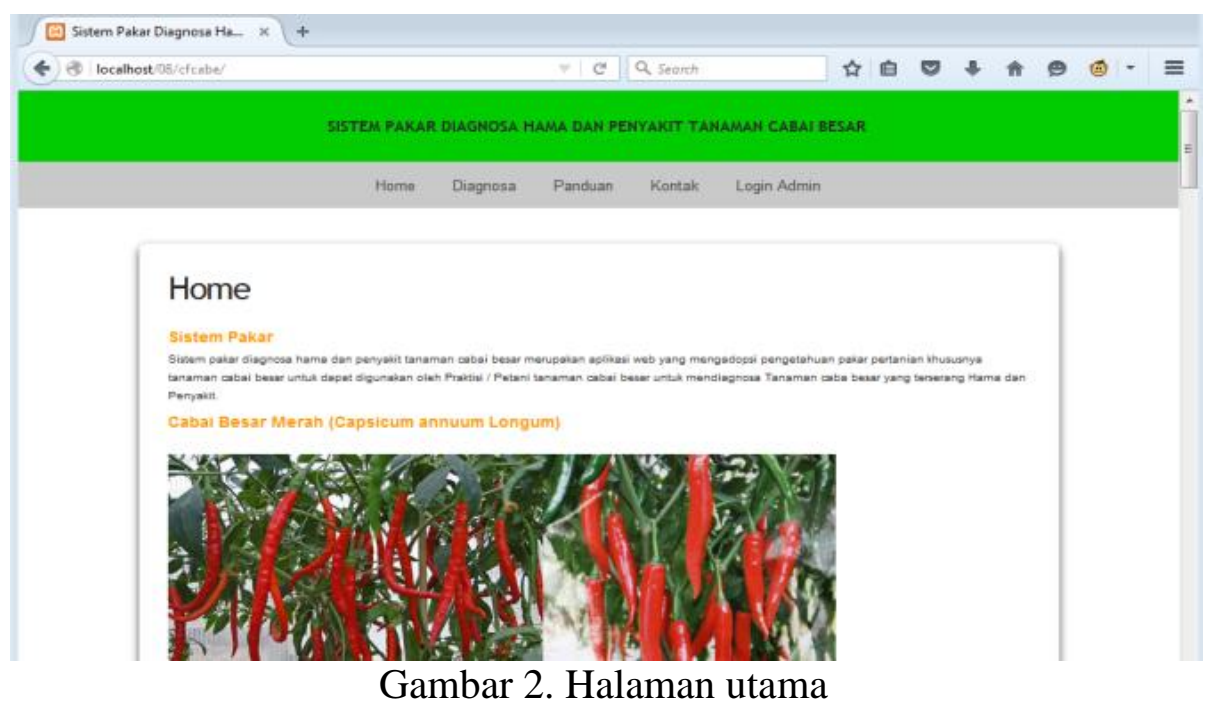

\section{b. Tampilan halaman form diagnosa}

Halaman form diagnosa hama dan penyakit berisi form dalam bentuk list gejala untuk dipilih sesuai gejala yang dialami dan terdapat tombol submit diagnosa di bagian bawah untuk melakukan diagnosa dan mendapatkan hasil analisa diagnosa hama dan penyakit. Tampilan form diagnosa hama dan penyakit seperti pada Gambar 3.

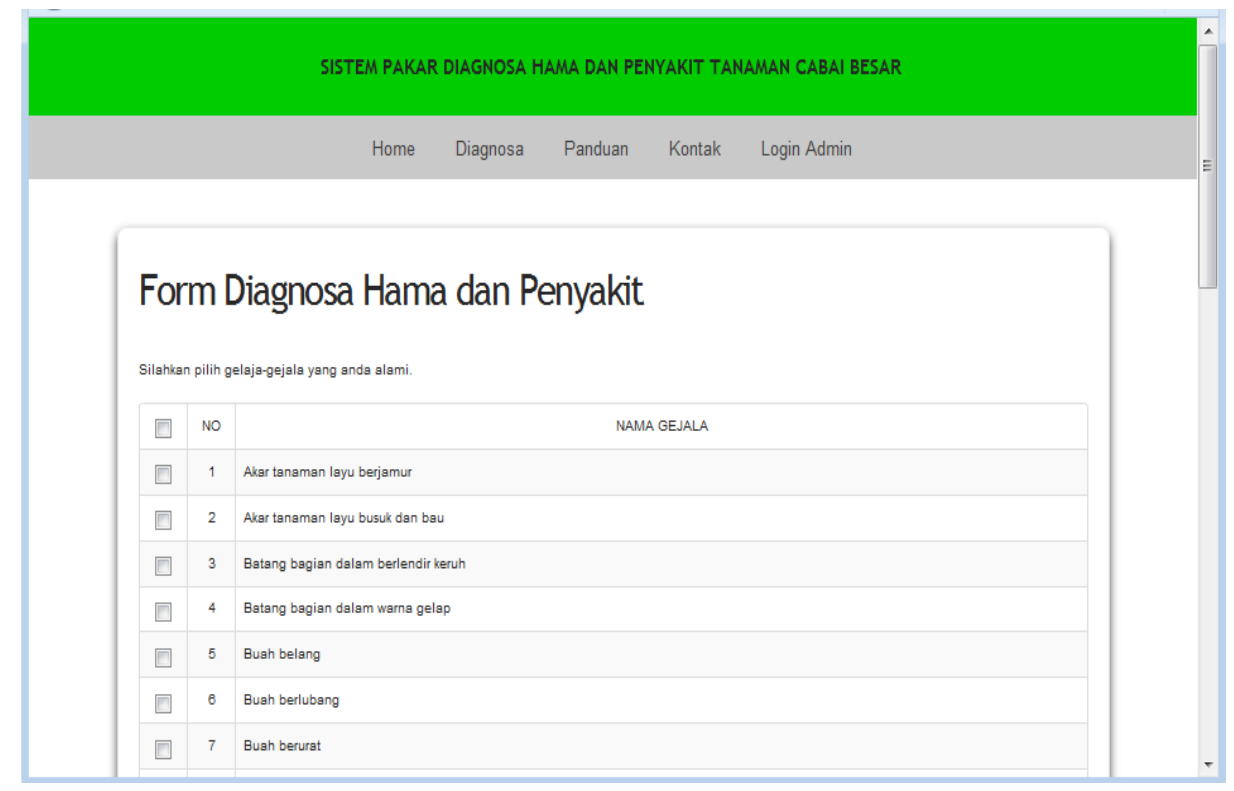

Gambar 3. Halaman form diagnosa

\section{c. Tampilan halaman hasil diagnosa}

Halaman hasil diagnosa didapatkan setelah user memilih gejala yang dialami kemudian menekan tombol submit diagnosa. Halaman hasil diagnosa berisi list gejala yang dipilih lalu hasil dari perhitungan perkiraan serangan hama atau penyakit sesuai dengan gejala yang dipilih dan tombol untuk mencetak hasil diagnosa hama dan penyakit. Hasil diagnosa hama dan penyakit tanaman cabai ditunjukkan pada Gambar 4. 


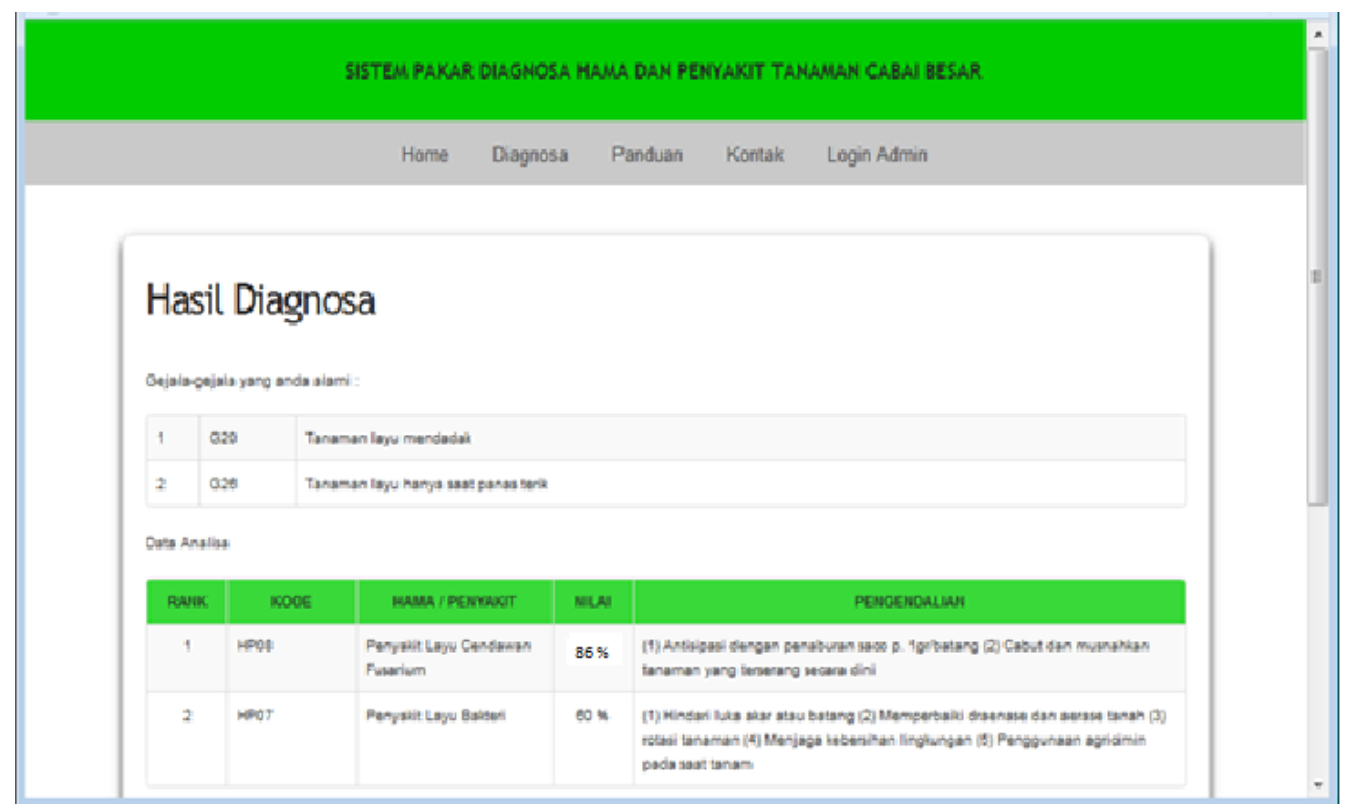

Gambar 4. Halaman hasil diagnosa

\section{d. Tampilan halaman cetak hasil diagnosa}

Halaman cetak laporan hasil diagnosa seperti pada Gambar 5, diperoleh dari proses diagnosa dan mendapatkan hasil diagnosa kemudian menekan tombol cetak laporan.

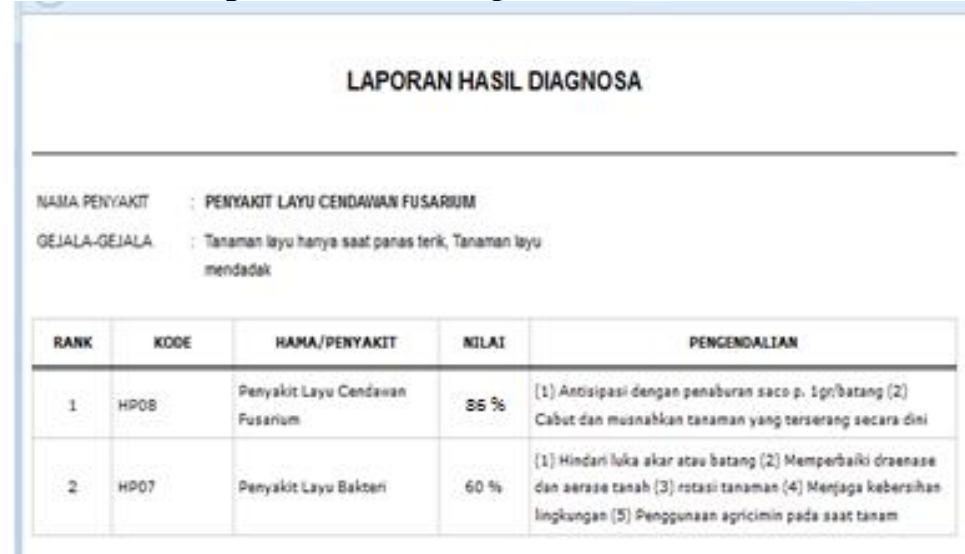

Gambar 5. Halaman cetak hasil diagnosa

\subsection{Pengujian Sistem}

\subsubsection{Pengujian Fungsional Sistem}

Hasil pengujian fungsional dengan metode black box secara keseluruhan dapat dilihat pada Tabel 7.

Tabel 7. Rekapitulasi pengujian fungsional

\begin{tabular}{|l|l|l|}
\hline No. & \multicolumn{1}{|c|}{ Butir Pengujian } & \multicolumn{1}{|c|}{ Hasil } \\
\hline 1 & Pengujian diagnosa & Sesuai \\
\hline 2 & Pengujian login & Sesuai \\
\hline 3 & $\begin{array}{l}\text { Pengujian input data hama dan } \\
\text { penyakit }\end{array}$ & Sesuai \\
\hline 4 & Pengujian input data gejala & Sesuai \\
\hline 5 & Pengujian input data pengetahuan & Sesuai \\
\hline
\end{tabular}


Berdasarkan hasil uji fungsionalitas sistem dapat disimpulkan bahwa sistem pakar diagnosa hama dan penyakit tanaman cabai besar menggunakan metode certainty factor ini sudah sesuai antara hasil masukan yang diberikan ke dalam sistem dengan hasil keluaran yang diharapkan dari sistem.

\subsubsection{Diagnosa Sistem vs Pakar}

Perbandingan hasil diagnosa sistem dan hasil diagnosa seorang pakar ditunjukkan pada Tabel 8.

Tabel 8. Hasil Diagnosa Sistem vs Pakar

\begin{tabular}{|c|c|c|c|}
\hline No & Gejala & Hasil Sistem Pakar & $\begin{array}{c}\text { Hasil Pengamatan } \\
\text { Pakar }\end{array}$ \\
\hline 1 & $\begin{array}{l}\text { - Tanaman layu mendadak } \\
\text { - Tanaman layu hanya saat } \\
\text { panas terik }\end{array}$ & $\begin{array}{l}\text { - Penyakit Layu Cendawan } \\
\text { Fusarium (86\%) } \\
\text { - Penyakit Layu Bakteri }(60 \%)\end{array}$ & - Layu Cendawan \\
\hline 2 & $\begin{array}{l}\text { - Buah kerdil } \\
\text { - Daun belang hijau kuning } \\
\text { - Buah belang }\end{array}$ & $\begin{array}{l}\text { - Penyakit Mozaik (Keriting) } \\
(77.8 \%) \\
\text { - Hama Tungau }(60 \%)\end{array}$ & - Keriting \\
\hline 3 & $\begin{array}{l}\text { - Daun melengkung ke } \\
\text { bawah } \\
\text { - Daun terdapat serat benang } \\
\text { - Daun berlubang }\end{array}$ & $\begin{array}{l}\text { - Hama Tungau (86\%) } \\
\text { - Hama Ulat Grayak }(70 \%) \\
\text { - Hama Kutu Daun }(60 \%)\end{array}$ & $\begin{array}{ll}\text { - } & \text { Ulat Grayak } \\
\text { - } & \text { Tungau }\end{array}$ \\
\hline 4 & $\begin{array}{l}\text { - Buah busuk kering } \\
\text { - Cabang busuk kering } \\
\text { - Buah belang }\end{array}$ & $\begin{array}{l}\text { - Penyakit Antraknosa (Patek) } \\
(96 \%) \\
\text { - Penyakit Mozaik (Keriting) } \\
(50 \%)\end{array}$ & - Penyakit Patek \\
\hline 5 & $\begin{array}{l}\text { - Buah busuk basah } \\
\text { - Buah rontok } \\
\text { - Daun melengkung ke } \\
\text { bawah }\end{array}$ & $\begin{array}{l}\text { - Hama Lalat Buah }(86 \%) \\
\text { - Hama Tungau }(70 \%) \\
\text { - Hama Kutu Daun }(60 \%) \\
\text { - Penyakit Antraknosa (Patek) } \\
\quad(60 \%)\end{array}$ & - Lalat Buah \\
\hline 6 & $\begin{array}{l}\text { - Buah busuk basah } \\
\text { - Buah rontok } \\
\text { - Daun melengkung ke } \\
\text { bawah }\end{array}$ & $\begin{array}{l}\text { - Hama Lalat Buah }(86 \%) \\
\text { - Hama Tungau }(70 \%) \\
\text { - Hama Kutu Daun }(60 \%) \\
\text { - Penyakit Antraknosa (Patek) } \\
(60 \%)\end{array}$ & - Lalat Buah \\
\hline 7 & $\begin{array}{l}\text { - Daun belang hijau kuning } \\
\text { - Daun keriput }\end{array}$ & $\begin{array}{l}\text { - Penyakit Mozaik (Keriting) } \\
(96 \%) \\
\text { - Hama Tungau }(70 \%) \\
\text { - Hama Kutu Daun }(70 \%) \\
\end{array}$ & - Mozaik \\
\hline 8 & $\begin{array}{l}\text { - Akar tanaman layu busuk } \\
\text { dan bau } \\
\text { - Batang bagian dalam } \\
\text { warna gelap } \\
\text { - Tanaman layu mendadak }\end{array}$ & $\begin{array}{l}\text { - Penyakit Layu Bakteri }(79,2 \%) \\
\text { - Penyakit Layu Cendawan } \\
\text { Fusarium }(70 \%)\end{array}$ & - Layu Bakteri \\
\hline 9 & $\begin{array}{l}\text { - Daun berbintik putih } \\
\text { - Daun melengkung ke } \\
\text { bawah }\end{array}$ & $\begin{array}{l}\text { - Hama Kutu Daun (76\%) } \\
\text { - Hama Tungau (70\%) }\end{array}$ & - Kutu Daun \\
\hline 10 & $\begin{array}{l}\text { - Bunga kerdil } \\
\text { - Bunga keriput } \\
\text { - Daun melengkung ke atas }\end{array}$ & - Hama Thrips $(80,2 \%)$ & - Thrips \\
\hline
\end{tabular}


Hasil diagnosa di atas menunjukkan bahwa diagnosa sistem pakar dengan diagnosa seorang pakar adalah sama.

Berdasarkan hasil pengujian fungsionalitas dan perbandingan hasil diagnosa sistem dengan pakar, dapat disimpulkan bahwa sistem pakar yang dibuat dapat digunakan untuk mendiagnosa hama dan penyakit tanaman cabai besar.

\section{KESIMPULAN DAN SARAN}

\subsection{Kesimpulan}

Berdasarkan hasil dan pembahasan yang dikerjakan dengan judul Sistem Pakar Diagnosa Hama dan Penyakit Tanaman Cabai Besar Menggunakan Metode Certainty Factor, dapat diambil kesimpulan sebagai berikut :

a. Telah dibuat Sistem Pakar Diagnosa Hama dan Penyakit Tanaman Cabai Besar Menggunakan Metode Certainty Factor pada Organization for Industrial, Spiritual and Cultural Advancement (OISCA) Training Centre Karanganyar.

b. Perbandingan hasil diagnosa sistem dengan pakar menunjukkan bahwa sistem dapat mendiagnosa hama dan penyakit tanaman cabai besar dengan hasil layaknya diagnosa seorang pakar.

\subsection{Saran}

Sistem Pakar Diagnosa Hama dan Penyakit Tanaman Cabai Besar Menggunakan Metode Certainty Factor telah selesai dibuat dan untuk pengembangan penelitian berikutnya adalah:

a. Sistem pakar ini menggunakan metode perhitungan cartainty factor dan sistem pakar serupa masih dapat dibuat dengan menggunakan metode lainnya untuk didapatkan hasil yang lebih baik dan sesuai kebutuhan.

b. Sistem pakar ini dibuat dengan mencakup lokasi wilayah Kecamatan Matesih Kabupaten Karanganyar dan sekitarnya dan masih dapat dikembangkan untuk daerah lain dengan iklim dan jenis penyakit yang mungkin terdapat tambahan maupun perbedaan.

\section{DAFTAR PUSTAKA}

Anhar. (2010). Panduan Menguasai PHP \& MySQL Secara Otodidak. Jakarta: Mediakita. Hamid, A., \& Haryanto, M. (2012). Untung Besar dari Bertanam Cabai Hibrida. Jakarta: AgroMedia.

Kandaga, T., \& Sarean, R. B. (2010). Konsep dan Perancangan Code-Completion untuk PHP. Jurnal Informatika, Vol. 6, No.1 , 95-103.

Kaswidjanti, W. (2011). Implementasi mesin inferensi fuzzy (studi kasus sistem pakar untuk mendiagnosa penyakit tanaman cabe merah). Telematika, Vol. 7, No. 2 , 129138.

Khasanah, N., Utami, Y. R., \& Nugroho, D. (2012). Penerapan Metode Certainty Factor Dalam Mendiagnosa Dini Penyakit Telinga Hidung Dan Tenggorokan. Jurnal Ilmiah SINUS, Vol. 10, No. 2 , 15-26.

Rochana, S., Kusumaningrum, A., \& Utami, Y. R. (2017). Implementasi Fuzzy Logic dalam Sistem Pakar untuk Mendeteksi Penyakit Kanker Serviks. Jurnal Ilmiah SINUS, Vol. 15, No. 1, 27-38. 
Setianto, Y., Widada, B., \& Utami, Y. R. (2017). Sistem Pakar Untuk Mengetahui Hama Wereng Pada Tanaman Padi Beserta Solusi dengan Menggunakan Logika Fuzzy Tsukamoto. Jurnal Teknologi Informasi dan Komunikasi, Vol. 5, No. 1 , 56-64.

Sihombing, M. Y., \& Ayub, M. (2010). 2010, Sistem Pakar Berbasis Web sebagai Alat Bantu Pembelajaran Mahasiswa Kedokteran untuk Penyakit Kanker Darah pada Anak,. Jurnal Informatika, Vol. 6, No.1 , 1-10.

Sutojo. (2010). Kecerdasan Buatan. Yogyakarta: Andi.

Ulya, D., Putri, R. R., \& Furqon, M. T. (2014). Sistem Pakar Diagnosa Penyakit Kulit pada Anak menggunakan Metode Certainty Factor. Doro Jurnal, Vol. 4, No.5 , 1-12. 